\title{
Identification, origin, and evolution of leaf nodulating symbionts of Sericanthe (Rubiaceae)
}

\author{
Benny Lemaire $^{1^{*}}$, Elmar Robbrecht ${ }^{2}$, Braam van Wyk $^{3}$, Sandra Van Oevelen ${ }^{4}$, Brecht Verstraete $^{1}$, \\ Els Prinsen ${ }^{4}$, Erik Smets ${ }^{1,5,6}$, and Steven Dessein ${ }^{2}$ \\ ${ }_{1}^{1}$ Laboratory of Plant Systematics, K.U.Leuven, Kasteelpark Arenberg 31, PO Box 2437, BE-3001 Leuven, Belgium \\ ${ }^{2}$ National Botanic Garden of Belgium, Domein van Bouchout, BE-1860 Meise, Belgium \\ ${ }^{3}$ H.G.W.J. Schweickerdt Herbarium, University of Pretoria, Pretoria 0002, South Africa \\ ${ }^{4}$ Laboratory of Plant Biochemistry and Physiology, University of Antwerp, Universiteitsplein 1, BE-2610 Antwerp, \\ Belgium \\ ${ }_{5}^{5}$ Netherlands Centre for Biodiversity Naturalis, PO Box 9517, 2300 RA Leiden, the Netherlands \\ ${ }^{5}$ National Herbarium of the Netherlands, Leiden University, PO Box 9514, 2300 RA Leiden, the Netherlands \\ * For correspondence. E-mail: Benny.Lemaire@bio.kuleuven.be; Tel.: 0032-16-32-86-36; Fax: 0032-16-32-19-55
}

\begin{abstract}
Bacterial leaf symbiosis is an intimate association between bacteria and plants in which endosymbionts are housed within leaf nodules. This phenomenon has been reported in three genera of Rubiaceae (Pavetta, Psychotria, and Sericanthe), but the bacterial partner has only been identified in Psychotria and Pavetta. Here we report the identification of symbiotic bacteria in two leaf nodulating Sericanthe species. Using $16 \mathrm{~S}$ rRNA data and common housekeeping genetic markers ( $r e c A$ and gyrB) we studied the phylogenetic relationships of bacterial endosymbionts in Rubiaceae. Endosymbionts of leaf nodulating Rubiaceae were found to be closely related and were placed as a monophyletic group within the genus Burkholderia ( $\beta$-Proteobacteria). The phylogenetic analyses revealed a pattern of strict host specificity and placed the two investigated endosymbionts at two distinct positions in the topology of the tree, suggesting at least two different evolutionary origins. The degree of sequence divergence between the Sericanthe endosymbionts and their relatives was large enough to propose the Sericanthe endosymbionts as new species ('Candidatus Burkholderia andongensis' and 'Candidatus Burkholderia petitii'). In a second part of this study, the pylogenetic relationships among nodulating and non-nodulating Sericanthe species were investigated using sequence data from six chloroplast regions $(r p s 16, \operatorname{trn} G, \operatorname{trnL}-\operatorname{trn} F$, petD, petA$p s b J$, and atpI-atpH). Overall, genetic variation among the plastid markers was insufficient to enable phylogenetic estimation. However, our results could not rule out the possibility that bacterial leaf symbiosis originated once in a common ancestor of the Sericanthe species.
\end{abstract}

Keywords: Burkholderia, endosymbionts, bacterial leaf nodulation, Sericanthe, Rubiaceae

\begin{abstract}
About 500 species of Rubiaceae are known to house bacterial endosymbionts within internal cavities in the leaf lamina, referred to as bacterial leaf nodules or leaf galls (Miller, 1990). Endosymbionts are persistent and obligate associates of the host plants and are required for the successful development and reproduction of their hosts (Gordon, 1963; Miller, 1990). However, knowledge about the exact benefits conferred by these endosymbionts is still incomplete. Many studies have proposed that the endophytes of nodulated species are involved in the production of phytohormones (reviewed in Miller, 1990). From the endosymbiont's perspective, the colonization of internal plant tissues may provide a stable, uniform, and protective environment.

Leaf nodulated plant species are limited to three distantly related genera: Pa v e t $t$ a L., Psychotria L., and Sericanthe Robbr. These three genera of the Rubiaceae family have no close phylogenetic affinity and belong to distant alliances. Psychotria is a member of the subfamily Rubioideae and belongs to the tribe Psychotrieae. Pavetta and Sericanthe belong to the subfamily Cinchonoideae and have been placed in the tribes Pavetteae and Coffeeae, respectively (Robbrecht and Manen, 2006).

Morphological observations of bacterial endosymbionts have been conducted in all rubiaceous genera (Pavetta and Psychotria in Miller, 1990; Sericanthe in Van Hove, 1972, referred to by the author as 'Neorosea'). Still, attempts to cultivate and characterize these leaf nodulating bacteria associated have been
\end{abstract}


unsuccessful to date. Molecular sequencing analyses however now enable the identification of uncultivable endosymbionts. Indeed, the taxonomic position of the endosymbionts of Pavetta and Psychotria has been recently clarified (Van Oevelen et al., 2001, 2002, 2004; Lemaire et al., 2011). These studies have demonstrated that every nodulating species hosts its own unique Burkholderia endosymbiont. In contrast, the bacterial leaf endosymbionts within the genus Sericanthe remain unknown.

The genus Sericanthe is composed mostly by shrubs that occupy rain forests, woodlands, savannas and (sub)montane habitats in Southern and Western Africa. Many Sericanthe species have a very restricted distribution, as reflected by their rarity and infrequent collection (Robbrecht, 1978a). For a complete description of the geographical distribution of all Sericanthe species see Robbrecht (1978b).

In Sericanthe, leaf nodules have been reported in 11 or 12 out of 17 species (Robbrecht, 1978a). This small nodulating genus contrasts with the more specious genera Pavetta and Psychotria, which contain approximately 350 and 80 nodulating species, respectively. Bacterial leaf galls of nodulated Sericanthe species are always located on the abaxial side of the leaf and are hardly visible from the adaxial side. The shape and distribution of the nodules on the leaves differ substantially among species and range from linear galls along the mid-vein (e.g. Sericanthe andongensis) to dot-shaped or branched nodules scattered in the leaf blade (e.g. Sericanthe petitii) (Robbrecht, 1978a, 1981). A similar variation in nodule localization and morphology has been reported in Pavetta and Psychotria (Bremekamp, 1933).

In the present study, we focus on the endosymbiont identification and evolutionary history of bacterial leaf symbiosis in the genus Sericanthe. We propose the hypotheses that (1) leaf nodulated Sericanthe species accommodate their own specific endosymbionts and that (2) the bacteria-plant interaction is the result of an ancient and single infection event within an ancestral leaf nodulated Sericanthe host.

\section{Material and Methods}

\section{Taxon sampling}

Silica-dried material from $S$. andongensis and $S$. petitii were collected during botanical field expeditions in South Africa, Cameroon and Zambia. Five accessions of $S$. andongensis and two accessions of $S$. petitii were sampled from different regions in the field and were used to identify the bacterial endosymbionts. A detailed list of sampled species, voucher information and localities is given in Table 1. To determine the phylogenetic position of the endosymbionts of Sericanthe, we included related bacterial sequences of Burkholderia obtained from GenBank (Table 1).

Three additional Sericanthe species (i.e. S. auriculata, S. odoratissima, S. spec. nov.), the latter two of which were collected in the field and the first of which was obtained from an herbarium sample at the National Botanic Garden of Belgium (BR), were included in this study to construct the host phylogeny (Table 1).

\section{DNA extraction, amplification, cloning, and sequencing}

Before extraction of the bacterial DNA the silica-dried leaves were rinsed with $70 \%$ ethanol to avoid bacterial contamination. Total DNA was extracted from silica-dried collections and herbarium specimens (BR) using the modified CTAB protocol of Tel-Zur et al. (1999). Bacterial DNA (16S rRNA, recA and

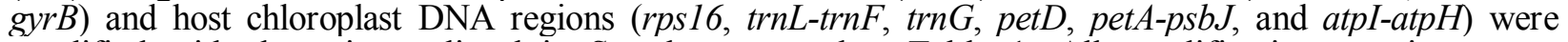
amplified with the primers listed in Supplementary data Table 1. All amplification reactions were performed using a GeneAmp PCR System 9700 (Applied Biosystems, USA). Each amplification reaction was performed in $25 \mu \mathrm{l}$ reaction mix containing $1 \mu \mathrm{l}$ total DNA, $16 \mu \mathrm{l} \mathrm{H}_{2} 0,2.5 \mu \mathrm{l} 10 \times$ PCR buffer, $0.75 \mu \mathrm{l}$ $25 \mu \mathrm{M} \mathrm{MgCl}, 1 \mu \mathrm{l}$ of $20 \mu \mathrm{M}$ forward and reverse primers, $2.5 \mu \mathrm{l} 2 \mu \mathrm{M} \mathrm{dNTP}$, and $0.2 \mu \mathrm{l} \mathrm{Ta} q$ DNA polymerase. PCR amplification of endosymbiont DNA regions was performed with PCR parameters as described previously (Lemaire et al., 2011). Amplification of rps 16, trnL-trnF, trnG, petA-psbJ, and atpIatp $H$ was carried out under the following conditions: $94^{\circ} \mathrm{C}$ for $3 \mathrm{~min} ; 30$ cycles at $94^{\circ} \mathrm{C}$ for $60 \mathrm{sec}, 52^{\circ} \mathrm{C}$ for $60 \mathrm{sec}, 72^{\circ} \mathrm{C}$ for $90 \mathrm{sec}$; final extension at $72^{\circ} \mathrm{C}$ for $5 \mathrm{~min}$. The amplification parameters for petD were $94^{\circ} \mathrm{C}$ for $3 \mathrm{~min} ; 30$ cycles at $94^{\circ} \mathrm{C}$ for $60 \mathrm{sec}, 55^{\circ} \mathrm{C}$ for $60 \mathrm{sec}, 72^{\circ} \mathrm{C}$ for $90 \mathrm{sec}$; final extension at $72^{\circ} \mathrm{C}$ for 5 min. Amplified products were purified using a modification of the Exo/SAP enzyme cleaning protocol (Werle et al., 1994).

Amplified 16S rRNA products were cloned into a pGEM-T vector (Promega), according to the manufacturer's instructions, and transformed into JM109 E. coli by heat shock. Plasmid purification was obtained with a PureYield ${ }^{\mathrm{TM}}$ Plasmid Miniprep System (Promega).

Purified plasmids and PCR products were sent to Macrogen for sequencing (Macrogen Inc., Korea). 
Table 1. Taxon accession data with herbarium vouchers, silica-gel collections, (geographical) origins and GenBank accession numbers of leaf nodulated endosymbionts and host plants. Specimens were obtained from the National Botanic Garden of Belgium (BR). Underlined taxa represent accessions that were newly sequenced for this study.

\begin{tabular}{|c|c|c|c|c|c|}
\hline \multirow{2}{*}{ Taxon } & \multirow{2}{*}{ Strain/Voucher } & \multirow{2}{*}{ Origin } & \multicolumn{3}{|c|}{ GenBank accession number } \\
\hline & & & 16S rRNA & $\operatorname{rec} A$ & gyrB \\
\hline Burkholderia ambifaria & LMG 19182 & Pea, rhizosphere & HQ849072 & HQ849130 & HQ849186 \\
\hline Burkholderia caribensis & LMG 18531 & Vertisol & HQ849077 & HQ849135 & HQ849190 \\
\hline Burkholderia cepacia & LMG 1223 & Allium cepa & HQ849078 & JF295011 & HQ849191 \\
\hline Burkholderia fungorum & LMG 16225 & Phanerochaete chrysosporium, fungus & HQ849081 & HQ849138 & HQ849194 \\
\hline Burkholderia gladioli & LMG 11626 & Poisoned bongkrek & HQ849082 & HQ849139 & HQ849195 \\
\hline Burkholderia glathei & LMG 14190 & Lateritic soil & U96935 & AY619666 & EU024198 \\
\hline Burkholderia glathei & LMG 14190 & Lateritic soil & HQ849084 & HQ849141 & HQ849197 \\
\hline Burkholderia graminis & LMG 18924 & Maize senescent root system & HQ849086 & HQ849143 & HQ849199 \\
\hline Burkholderia kururiensis & LMG 19447 & Aquifer sample & HQ849088 & HQ849145 & HQ849201 \\
\hline Burkholderia multivorans & LMG 13010 & Cystic fibrosis patient & HQ849090 & - & HQ849203 \\
\hline Burkholderia oklahomensis & LMG 23618 & Soil & HQ849092 & HQ849148 & HQ849205 \\
\hline Burkholderia plantarii & LMG 9035 & Oryza sativa, seedling & HQ849098 & HQ849153 & HQ849210 \\
\hline Burkholderia stabilis & LMG 14294 & Cystic fibrosis, patient & HQ849103 & HQ849159 & JF295010 \\
\hline Burkholderia tropica & LMG 22274 & Sugarcane, roots & HQ849105 & HQ849161 & HQ849216 \\
\hline Burkholderia tuberum & LMG 21444 & Aspalathus carnosa, root nodule & HQ849106 & HQ849162 & HQ849217 \\
\hline Burkholderia vietnamiensis & LMG 10929 & Oryza sativa, rhizosphere soil & HQ849107 & HQ849163 & HQ849218 \\
\hline $\begin{array}{l}\text { Candidatus Burkholderia } \\
\text { andongensis }\end{array}$ & BL 259 (BR) & $\begin{array}{l}\text { Sericanthe andongensis (Hiern) Robbr, leaf } \\
\text { nodules; South Africa, Louis Trichardt }\end{array}$ & - & JF916912 & JF916907 \\
\hline $\begin{array}{l}\text { Candidatus Burkholderia } \\
\text { andongensis }\end{array}$ & BL 271 (BR) & $\begin{array}{l}\text { Sericanthe andongensis (Hiem) Robbr, leaf } \\
\text { nodules; South Africa, Vhembe }\end{array}$ & JF916918 & JF916913 & JF916908 \\
\hline $\begin{array}{l}\text { Candidatus Burkholderia } \\
\text { andongensis }\end{array}$ & BL $286(\mathrm{BR})$ & $\begin{array}{l}\text { Sericanthe andongensis (Hiern) Robbr, leaf } \\
\text { nodules; South Africa, Vhembe }\end{array}$ & JF916919 & - & JF916906 \\
\hline$\frac{\text { Candidatus Burkholderia }}{\text { andongensis }}$ & BL 293 (BR) & $\begin{array}{l}\text { Sericanthe andongensis (Hiern) Robbr, leaf } \\
\text { nodules; South Africa, Tathe Vondo }\end{array}$ & $\mathrm{JFC}$ & JF916914 & JF916909 \\
\hline $\begin{array}{l}\text { Candidatus Burkholderia } \\
\text { andongensis }\end{array}$ & SD 1097 (BR) & $\begin{array}{l}\text { Sericanthe andongensis (Hiern) Robbr:, leaf } \\
\text { nodules; Zambia }\end{array}$ & JF916921 & JF916915 & JF916905 \\
\hline $\begin{array}{l}\text { Candidatus Burkholderia } \\
\text { calva }\end{array}$ & $1962-0512(\mathrm{BR})$ & Psychotria calva Hiern, leaf nodules; Unknown & HQ849116 & HQ849172 & JF295009 \\
\hline $\begin{array}{l}\text { Candidatus Burkholderia } \\
\text { calva }\end{array}$ & 1964-0306 (BR) & $\begin{array}{l}\text { Psychotria calva Hiern, leaf nodules; Ivory } \\
\text { Coast }\end{array}$ & HQ849117 & HQ849173 & HQ849227 \\
\hline $\begin{array}{l}\text { Candidatus Burkholderia } \\
\text { hispidae }\end{array}$ & SD $3176(\mathrm{BR})$ & $\begin{array}{l}\text { Pavetta hispida Hiern, leaf nodules; Cameroon, } \\
\text { Ebolowa }\end{array}$ & HQ849122 & HQ849178 & HQ849231 \\
\hline $\begin{array}{l}\text { Candidatus Burkholderia } \\
\text { hispidae }\end{array}$ & OL $732(\mathrm{BR})$ & $\begin{array}{l}\text { Pavetta hispida Hiern, leaf nodules; Cameroon, } \\
\text { Efoulan }\end{array}$ & HQ849123 & HQ849179 & HQ849232 \\
\hline $\begin{array}{l}\text { Candidatus Burkholderia } \\
\text { kirkii }\end{array}$ & $1953-6779(\mathrm{BR})$ & Psychotria kirkii Hiern, leaf nodules; Unknown & HQ849109 & HQ849165 & HQ849220 \\
\hline $\begin{array}{l}\text { Candidatus Burkholderia } \\
\text { kirkii }\end{array}$ & 2000-1946-61 (BR) & $\begin{array}{l}\text { Psychotria kirkii Hiern, leaf nodules; } \\
\text { D.R. Congo, Kantanga }\end{array}$ & HQ849110 & HQ849166 & HQ849221 \\
\hline $\begin{array}{l}\text { Candidatus Burkholderia } \\
\text { nigropunctata }\end{array}$ & PS 13 (BR) & $\begin{array}{l}\text { Psychotria nigropunctata Hiern; D.R. Congo, } \\
\text { Kisantu }\end{array}$ & HQ849118 & HQ849174 & HQ849228 \\
\hline $\begin{array}{l}\text { Candidatus Burkholderia } \\
\text { nigropunctata }\end{array}$ & SD 1849 (BR) & $\begin{array}{l}\text { Psychotria nigropunctata Hiern, leaf nodules; } \\
\text { Gabon, Bemboudié }\end{array}$ & HQ849119 & HQ849175 & JF295008 \\
\hline $\begin{array}{l}\text { Candidatus Burkholderia } \\
\text { pctitii }\end{array}$ & SD $1512(\mathrm{BR})$ & $\begin{array}{l}\text { Sericanthe aff. petitii (N.Hallé) Robbr, leaf } \\
\text { nodulcs; Camcroon, Mbikiliki }\end{array}$ & JF916923 & JF916916 & JF916911 \\
\hline $\begin{array}{l}\text { Candidatus Burkholderia } \\
\text { petitii }\end{array}$ & OL 658 (BR) & $\begin{array}{l}\text { Sericanthe aff. petitii (N.Hallé) Robbr, leaf } \\
\text { nodules; Cameroon, Efoulan }\end{array}$ & JF916922 & JF916917 & JF916910 \\
\hline $\begin{array}{l}\text { Candidatus Burkholderia } \\
\text { rigidae }\end{array}$ & OL 694 (BR) & $\begin{array}{l}\text { Pavetta rigida Hiern, leaf nodules; Cameroon, } \\
\text { Efoulan }\end{array}$ & HQ849120 & HQ849176 & HQ849229 \\
\hline $\begin{array}{l}\text { Candidatus Burkholderia } \\
\text { rigidae }\end{array}$ & OL 877 (BR) & $\begin{array}{l}\text { Pavetta rigida Hiern, leaf nodules; Cameroon, } \\
\text { Nkolakié }\end{array}$ & HQ849121 & HQ849177 & HQ849230 \\
\hline $\begin{array}{l}\text { Candidatus Burkholderia } \\
\text { schumannianae }\end{array}$ & SD 1099 (BR) & $\begin{array}{l}\text { Pavetta schumanniana F.Hoffm.ex K.Schum., } \\
\text { leaf nodules; South Africa }\end{array}$ & HQ849124 & HQ849180 & HQ849233 \\
\hline $\begin{array}{l}\text { Candidatus Burkholderia } \\
\text { schumannianae }\end{array}$ & 2001-9442-57 (BR) & $\begin{array}{l}\text { Pavetta schumanniana F.Hoffm.ex K.Schum., } \\
\text { leaf nodules; D.R. Congo }\end{array}$ & HQ849126 & HQ849182 & HQ849235 \\
\hline Ralstonia pickettii & $12 \mathrm{~J}$ & & NC010678 & NC010682 & NC010682 \\
\hline
\end{tabular}


Table 1. Continued

\begin{tabular}{|c|c|c|c|c|c|c|c|c|}
\hline \multirow{2}{*}{ Taxon } & \multirow{2}{*}{ Strain/Voucher } & \multirow{2}{*}{ Origin } & \multicolumn{6}{|c|}{ GenBank accession number } \\
\hline & & & $r p s 16$ & $\operatorname{trnL} L-t m F$ & $\operatorname{trn} G$ & petD & petA-psbJ & atpI-atpH \\
\hline Coffea stenophylla G.Don & $1937-0053(\mathrm{BR})$ & D.R. Congo & JF916942 & JF916964 & JF916953 & JF916975 & JF916931 & JF916924 \\
\hline Empogona kirkii Hook.f. & 1976-1052 (BR) & Zimbabwe & JF916943 & JF916965 & JF916954 & JF916976 & JF916932 & JF916925 \\
\hline $\begin{array}{l}\text { Sericanthe andongensis (Hiern) } \\
\text { Robbr. }\end{array}$ & SD 1097 (BR) & Zambia & JF916944 & JF916966 & JF916955 & JF916977 & JF916933 & - \\
\hline $\begin{array}{l}\text { Sericanthe andongensis (Hiern) } \\
\text { Robbr. }\end{array}$ & Chapman 6150 (BR) & Malawi & JF916945 & JF916967 & JF916956 & JF916978 & JF916934 & - \\
\hline $\begin{array}{l}\text { Sericanthe auriculata (Keay) } \\
\text { Robbr. }\end{array}$ & SD 1467 (BR) & Cameroon & JF916946 & JF916968 & JF916957 & JF916979 & JF916935 & JF916926 \\
\hline $\begin{array}{l}\text { Sericanthe auriculata (Keay) } \\
\text { Robbr. }\end{array}$ & SD $1516(B R)$ & Cameroon & JF916947 & JF916969 & JF916958 & JF916980 & JF916936 & JF916927 \\
\hline $\begin{array}{l}\text { Sericanthe odoratissima } \\
\text { (K.Schum.) Robbr. }\end{array}$ & Polhill et al. 5007A (BR) & Tanzania & JF916948 & JF916970 & JF916959 & - & JF916937 & - \\
\hline $\begin{array}{l}\text { Sericanthe odoratissima } \\
\text { (K.Schum.) Robbr. }\end{array}$ & Salubeni 3135 (BR) & Malawi & JF916949 & JF916971 & JF916960 & JF916981 & JF916938 & - \\
\hline $\begin{array}{l}\text { Sericanthe petitii (N.Hallé) } \\
\text { Robbr. }\end{array}$ & SD $1512(B R)$ & Cameroon & JF916950 & JF916972 & JF916961 & JF916982 & JF916939 & JF916928 \\
\hline $\begin{array}{l}\text { Sericanthe petitii (N.Hallé) } \\
\text { Robbr. }\end{array}$ & OL $658(\mathrm{BR})$ & Cameroon & JF916951 & JF916973 & JF916962 & JF916983 & JF916940 & JF916929 \\
\hline Sericanthe spec. nov. & SD 2608 (BR) & Cameroon & JF916952 & JF916974 & JF916963 & JF916984 & JF916941 & JF916930 \\
\hline
\end{tabular}

\section{Phylogenetic analyses}

Sequences were assembled and edited using the program Geneious 5.0.3 (http://www.geneious.com). A preliminary sequence alignment was created with Muscle (Edgar, 2004) followed by manual adjustments with MacClade 4.04 (Maddison and Maddison, 2001). Molecular data were analyzed using Maximum Likelhood (ML) and Bayesian Inference (BI) criteria, both of which were implemented in the CIPRES web portal (http:// www.phylo.org). ML analyses were performed with RAxML-VI-HPC v2.0 using GTRGAMMA as the nucleotide substitution model (Stamatakis, 2006). We performed 100 RAxML runs and selected the best ML tree by comparing the likelihood scores. The robustness of the ML tree was calculated with multi-parametric bootstrap resampling and 1000 pseudo-replicates.

Model selection for the Bayesian analysis was conducted with MrModeltest v. 3.06 (Posada and Crandall, 1998) under the Akaike information criterion. For the different datasets, Modeltest selected the following models of evolution: petD - GTR; rps $16-\mathrm{GTR}+\mathrm{I}$; trnG - F81; trnL-trnF - HKY; petA-psbJ - HKY; atpI-atpH - GTR; 16S rRNA - GTR+I+G; recA - GTR $+\mathrm{I}+\mathrm{G} ;$; $g r B-\mathrm{GTR}+\mathrm{I}+\mathrm{G}$.

In the combined BI analyses, the concatenated datasets (petD + rps $16+\operatorname{trn} G+\operatorname{trn} L-\operatorname{trnF}+$ petA-psbJ + atpI$a t p H$ and 16S rRNA + recA + gyrB) were partitioned and the same models were assigned to the separate partitions as selected for the single analyses. Gaps in the chloroplast data were coded according to the simple indel coding method described by Simmons and Ochoterena (2000). Bayesian analyses were conducted with MrBayes 3.1 (Huelsenbeck and Ronquist, 2001; Ronquist and Huelsenbeck, 2003), and four Markov chains were ran simultaneously for five million generations and sampling trees every 100 generations. The $25 \%$ initial trees were discarded as conservative "burnin". Convergence of the chains was checked using Tracer v.1.4 (Rambaut and Drummond, 2007).

\section{Morphological observations}

Morphological observations of leaf material of $S$. andongensis (accession: Lemaire et al. 293) and $S$. petitii (accession: Lachenaud et al. 658) were conducted to illustrate the bacterial endosymbionts. Sections through leaf nodules were made with a razor blade and the dissected material was washed repeatedly in $70 \%$ ethanol and dehydrated in a 1:1 mixture of ethanol and dimethoxymethan (DMM) for 20 min and in pure DMM for $20 \mathrm{~min}$. After critical-point drying (CPD 030, BAL-TEC AG, Liechtenstein), dried samples were mounted onto aluminium stubs, coated with gold (SPI Module Sputter Coater, Spi Supplies, USA) and observed under a scanning electron microscope (JEOL JSM-6360; Jeol Ltd, Japan).

\section{Results and Discussion}

\section{Phylogenetic analyses of the endosymbiont data}

The use of $16 \mathrm{~S}$ rRNA, recA and gyrB data to infer the phylo-genetic relationships in the genus Burkholderia is 
quite common and offers high resolution at both high and low taxonomic levels (Payne et al., 2005; Tabacchioni et al., 2008). These genes have been shown to provide a robust framework to determine the phylogenetic placement of the symbiotic bacteria of leaf nodulating Rubiaceae, as previously described in Lemaire et al. (2011). In the present study, a similar approach was used to identify the endosymbionts of nodulating Sericanthe species: molecular identification of endosymbionts was first performed by 16S rRNA sequencing and $16 \mathrm{~S}$ rRNA BLAST searches, and $r e c A$ and gyrB genes were used to increase the relative discriminatory power.

Direct sequencing of full-length 16S rRNA from 10 clones per plant species produced consistent results and assigned the endosymbionts of the leaf nodulating Sericanthe species (S. andongensis and S. petitii) in the Burkholderia genus. This $\beta$-Proteobacteria genus also includes the endosymbionts of the two other nodulating genera of the family, Psychotria and Pavetta. Amplified recA and gyrB data with Burkholderia specific primers (Supplementary data Table 1) were analyzed in combination with the 16S rRNA data, including 19 nodulated endosymbionts and 14 related Burkholderia strains. The phylogenetic analyses of the separate datasets showed similar topologies, except for few terminal branches. The phylogenies produced separately by the three datasets (16S rRNA, recA and $g y r B$ ) are shown in supplementary data Fig. 1.

Both the BI and ML analyses produced similar tree topologies and support values (Fig. 1). A wellsupported clade (100\% Bayesian posterior probability, BPP / 99\% bootstrap support, BS) with endosymbionts of leaf nodulating Psychotria, Pavetta, and Sericanthe plants was recovered as sister to Burkholderia glathei. All $S$. andongensis endosymbionts were positioned in a clade with maximum support that was sister to the endosymbionts of Pavetta rigida and Pavetta hispida. The intersequence similarities between the lineages from both clades ranged from 96\% (Candidatus Burkholderia andongensis vs. Candidatus Burkholderia hispidae) to $96.5 \%$ (Candidatus Burkholderia andongensis vs. Candidatus Burkholderia rigidae). The endosymbionts of S. petitii (100\% BPP / 100\% BS) were related to the 'Candidatus Burkholderia kirkii - Candidatus Burkholderia schumannianae' clade. The sequence divergence between both nodulating clades ranged from 94.6\% (Candidatus Burkholderia petitii vs Candidatus Burkholderia kirkii) to $95.0 \%$ (Candidatus Burkholderia petitii vs Candidatus Burkholderia schumannianae). These phylogenetic patterns indicate that endosymbiosis occurred multiple times in Rubiaceae, thus rejecting the hypothesis of a single infection event within the ancestor of extant leaf nodulated Pavetta, Psychotria, and Sericanthe species.

Five different samples of $S$. andongensis and two accessions of Sericanthe petitii from different geographical locations were investigated (Table 1). Intraspecific sequence variability among the endosymbiont strains of both species was low (average sequence identity between $S$. andongensis accessions: 16S rRNA - 100\%; recA $100 \%$; gyrB - 99.9\% and S. petitii accessions: $16 \mathrm{~S}$ rRNA - 100\%; recA - 99.8\%; gyrB - 100\%), suggesting a stable interaction and high specificity between host and endosymbiont. A similar pattern of host specificity has been documented in Psychotria and Pavetta (Van Oevelen et al., 2001, 2002, 2004; Lemaire et al., 2011). The phylogenetic analyses presented in this study show that the evolutionary distances between the Sericanthe endosymbionts and their closest relatives were significant compared to the observed intraspecific polymorphism to recognize these endosymbionts as novel Burkholderia species. As long as the cultivation of Sericanthe endosymbionts is not possible (E. Prinsen 2011, pers. comm.), we propose to record these endosymbionts under a Candidatus designation, according to Murray and Stockebrandt (1995). The endosymbionts of $S$. andongensis and $S$. petitii can be described using the specific epithets of their host species as specific epithets for these candidate Burkholderia species:

'Candidatus Burkholderia andongensis' (andongensis, from the specific epithet of the host plant) $(\beta$ proteobacteria, genus Burkholderia); NC; G-; R; NAS (GenBank nos. JF916921, JF916915, JF916905), oligonucleotide sequence complementary to unique region of $16 \mathrm{~S}$ rRNA gene 5'-ACTTCGTCCCTAATA ATGGATGGAG-3', oligonucleotide sequence complementary to unique region of recA $5^{\prime}$ CGCGTTCATCGATGCCGAAC ACGCGCTC-3', oligonucleotide sequence complementary to unique region of gyrB gene 5'-TCGCACGGCGTCGTGCAG AACCGTGAAGT-3'; S (S. andongensis, leaf galls). Lemaire et al. this study.

'Candidatus Burkholderia petitii' (petitii, from the specific epithet of the host plant) ( $\beta$-proteobacteria, genus Burkholderia); NC; G-; R; NAS (GenBank nos. JF916923, JF916916, JF916911), oligonucleotide sequence complementary to unique region of 16S rRNA gene 5'-GCTTCGGGGTTAATACCCCT GGGG-3', oligonucleotide sequence complementary to unique region of recA $5^{\prime}$ 'ACGTGCAATACGCCTCGAAGCTTGGC GTGAACGTGCCGGAT-3', oligonucleotide sequence complementary to unique region of gyrB gene 5'-ATGGAGTTC GCGCGTGGAGTCGTGCAGAACCGC-3'; S (S. petitii, leaf galls). Lemaire et al. this study. 


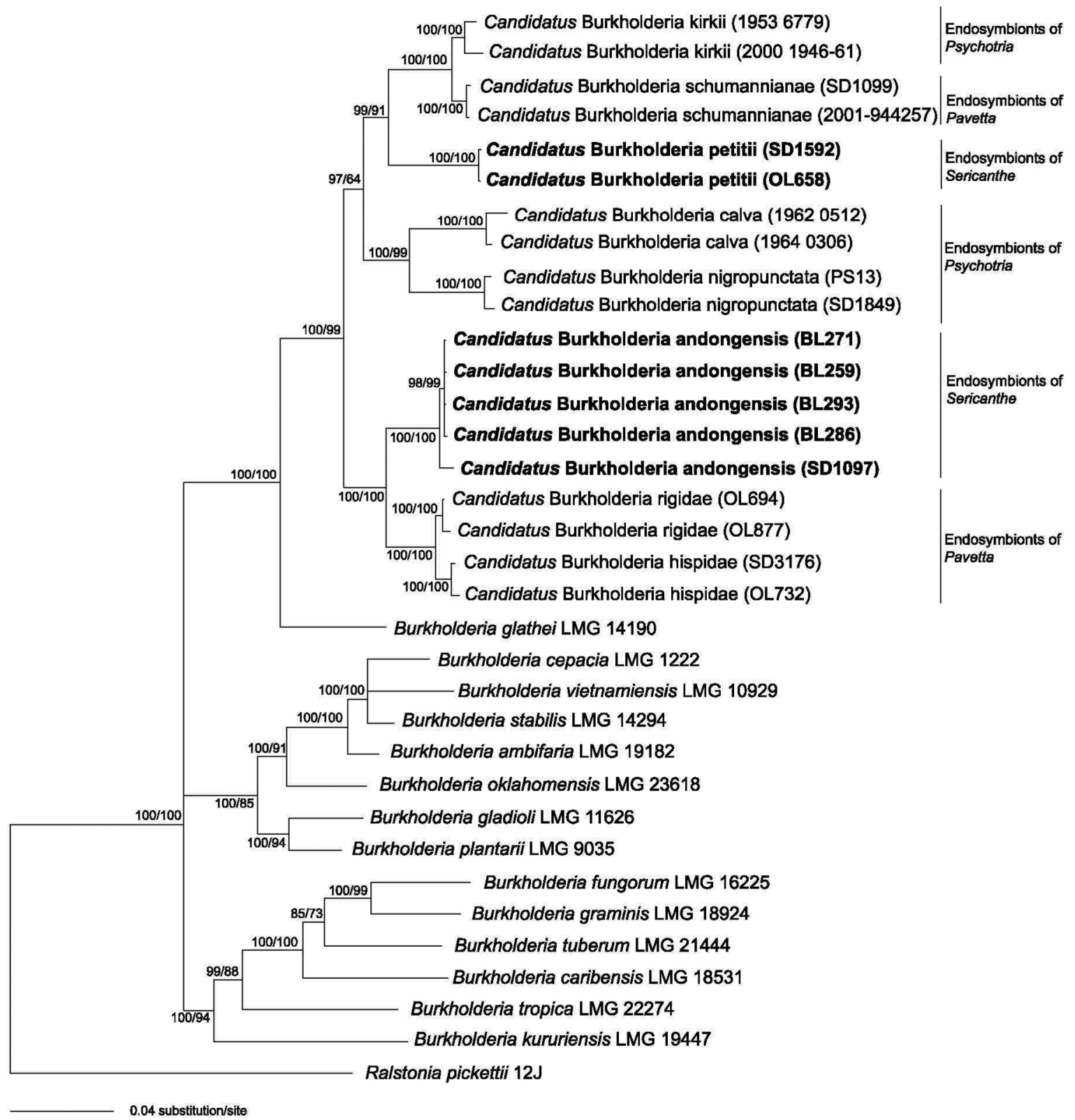

Fig. 1. Phylogenetic tree of bacterial endosymbionts based on $16 \mathrm{~S}$ rRNA, recA and gyrB data. Support values for the Bayesian and Maximum Likelihood analyses are given at the nodes (Bayesian posterior probabilities-bootstrap values from the Maximum Likelihood analysis). Branches of leaf nodulating endosymbionts are shown in bold. Names of newly proposed bacterial taxa are shown in bold. 

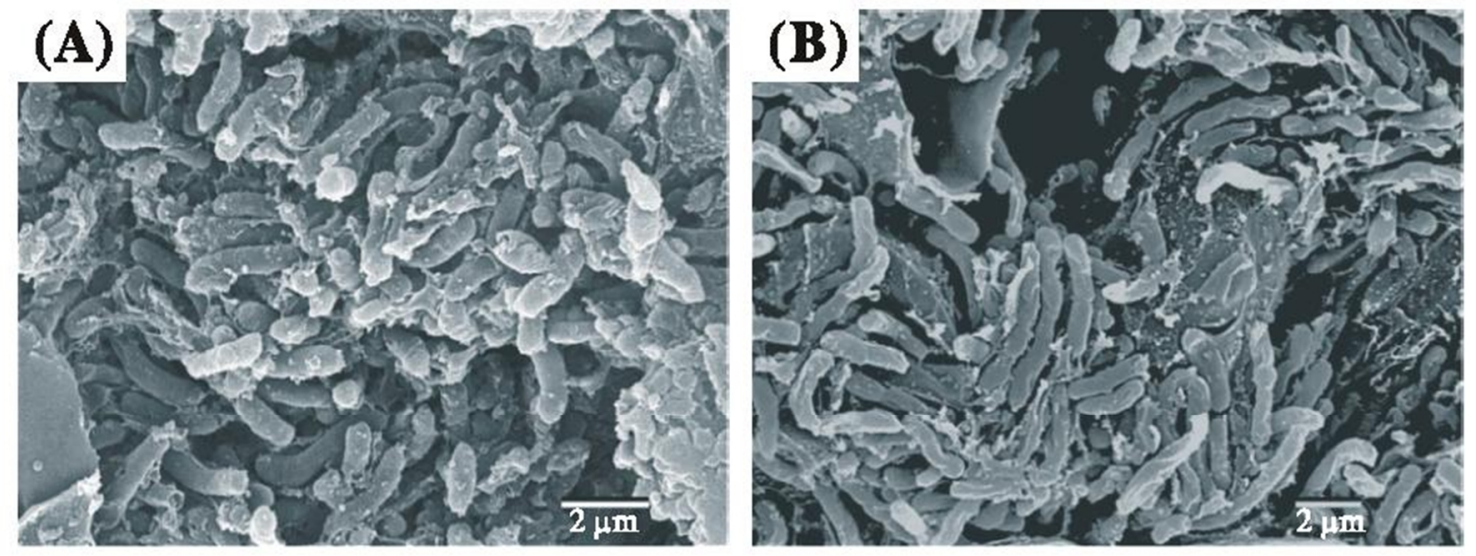

\title{
Fig. 2. SEM photographs of leaf nodulating endosymbionts of (A) $S$. petitii and (B) $S$. andongensis. Non-flagellated rod-shaped bacteria with a mean length of $2 \mu \mathrm{M}$ are visible.
}

\begin{abstract}
Morphological observations of leaf nodulating endosymbionts
The phylogentic analyses showed that leaf nodulated Sericanthe species accommodate a single species-specific endosymbiont. As a result, we were able to use the non-specific scanning electron microscopy to illustrate the endosymbionts in leaf nodule structures.

The bacterial endosymbionts within leaf nodules of $S$. andongensis and $S$. petitii are shown in Figs. 2A and B. Cross SEM sections of leaves were made to illustrate the bacterial morphology and the localization of the endosymbionts within nodules. The endosymbionts were restricted to the leaf gall structures and were clearly visible as rod shaped bacteria with an average length of $2 \mu \mathrm{m}$. No flagella were observed. The endosymbionts of Sericanthe were similar in size (1-2 $\mu \mathrm{m})$ and shape (bacterial rods) compared to the symbionts of Psychotria and Pavetta [see previous observations in the study of Va n Oevelen et al. (2004) and Lemaire et al. (2011)].
\end{abstract}

\section{Phylogenetic analyses of hosts}

To reconstruct the phylogenetic relationships between nodulated and non-nodulated Sericanthe species, 66 sequences were generated including six chloroplast regions (Table 1). Genetic variation among all chloroplast DNA regions was extremely low, ranging from $0.8 \%$ to $3.5 \%$ of variable sites (Supplementary data Table 2). In contrast, the alignment of the $16 \mathrm{~S}$ rRNA, $r e c A$ and gyrB sequences revealed higher levels of genetic variability. This difference in sequence variability between plants and bacteria is probably linked to different rates of molecular evolution associated with differences in body size, metabolic rate, DNA repair and generation time (Bromham, 2009). The phylogenetic relationships obtained from the six individual plastid markers were analyzed separately, and the resulting tree topologies were phylogenetically consistent. Consequently, the datasets were combined in subsequent analyses to increase phylogenetic resolution. Indels were binary coded and added to data matrices to increase support values. The Bayesian majority rule consensus tree and the Maximum Likelihood tree were congruent and are shown in Fig. 3. Overall, most phylogenetic relationships were resolved with high support values. However, the phylogenetic relationships between the nodulating Sericanthe species (showed in bold) and non-nodulating species were not completely resolved, showing a polytomy with members of $S$. andongensis, $S$. odoratissima, $S$. petitii, and $S$. auriculata. All nucleotide positions within the alignment were examined by eye and no single character was informative to resolve this node. Nevertheless, the observed phylogenetic relationships in this study do not rule out the possibility that bacterial endosymbiosis evolved in a parsimonious way, as demonstrated for other nodulated genera, i.e. Psychotria (Andersson, 2002) and Pa v et t a (De Block et al. unpublished). 


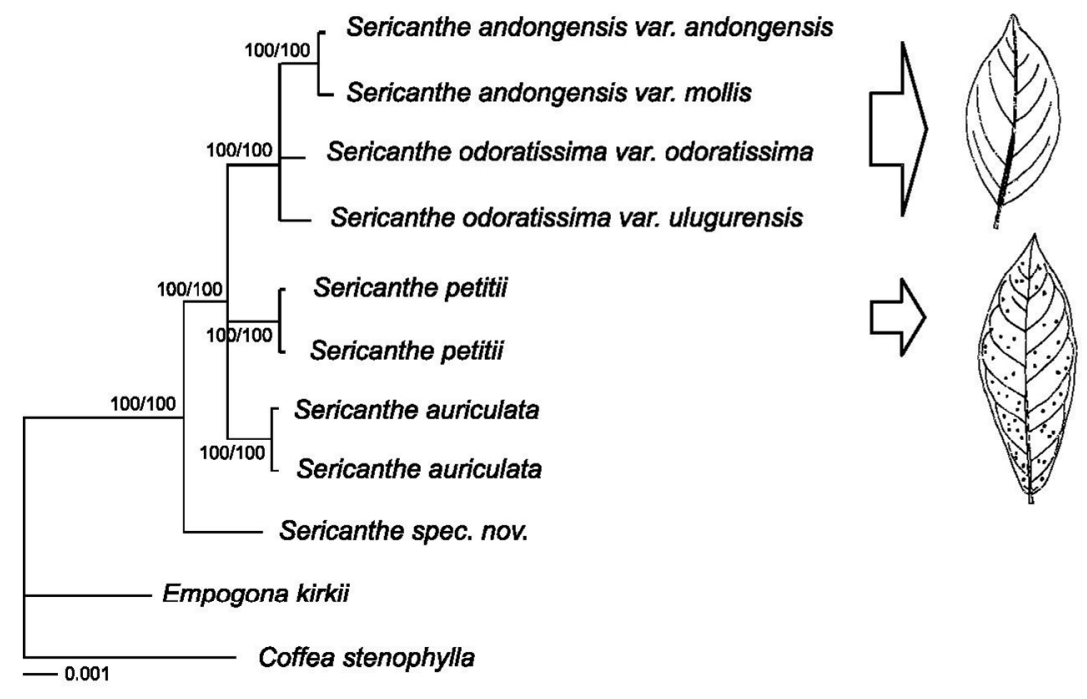

Fig. 3. Phylogenetic tree of hosts based on chloroplast data $(r p s 16, \operatorname{trn} G, \operatorname{trn} L-\operatorname{trn} F$, petD, petA-psbJ, and atpI-atpH). Support values for the Bayesian and Maximum Likelihood analyses are given at the nodes (Bayesian posterior probabilities - bootstrap values from the Maximum Likelihood analysis). Branches of leaf nodulated representatives are shown in bold. Leaves with leaf nodules are redrawn from Robbrecht (1978a). Top: leaf galls located along the midvein (S. andongensis var. andongensis). Bottom: leaf galls dispersed over the leaf blade (S. petitii).

\section{Conclusions}

The three nodulating genera have no close affinity and have been placed within different tribes and Rubiaceae subfamilies, which could lead to the conclusion that bacterial leaf nodule symbiosis originated independently in these three genera. Surprisingly, our results demonstrate that all endosymbionts of leaf nodulating Rubiaceae are closely related, but that neither the endosymbionts of Sericanthe nor the endosymbionts of Pavetta or Psychotria are monophyletic. These findings contrast with previous results showing that these three nodulating taxa are monophyletic (Andersson, 2002; Davis et al., 2007; T o s h et al., 2009; De Block et al., unpublished). The present results suggest thereby that the history of bacterial leaf symbiosis is characterized by horizontal symbiont transfers and reject the hypothesis of strict co-speciation between plant and bacteria at generic level.

\section{Acknowledgements}

The authors thank Elsa van Wyk and Magda Nel for their excellent support at the H.G.W.J. Schweickerdt Herbarium, Department of Plant Science, University of Pretoria (South Africa). We are also grateful to Norbert Hahn, who accompanied us during the expedition in South Africa. We thank the King Léopold III Fund and the Fund for Scientific Research - Flanders (FWO) which provided financial support for fieldwork in South Africa. This work was supported by the Institute for the Promotion of Innovation by Science and Technology in Flanders (IWT Vlaanderen, no. 71488). General financial support was provided by a grant of the Research Program of the Fund for Scientific Research - Flanders (Belgium) (FWO Vlaanderen, G.0343.09N) and the K.U. Leuven (OT/05/35).

\section{References}

Andersson, L. 2002. Relationships and generic circumscriptions in the Psychotria complex (Rubiaceae, Psychotrieae). Syst. Geogr. Pl. 72, 167-202.

Bremekamp, C.E.B. 1933. The bacteriophilous species of Psychotria. Lond. J. Bot. 71, 271-281.

Bromham, L. 2009. Why do species vary in their rate of molecular evolution? Biol. Lett. 5, 401-404.

Davis, A.P., M. Chester, O. Maurin, and M. Fay. 2007. Searching for the relatives of Coffea (Rubiaceae, Ixoroideae): the circumscription and phylogeny of Coffeeae based on plastid sequence data and 
morphology. Am. J. Bot. 94, 313-329.

Edgar, R.C. 2004. MUSCLE: multiple sequence alignment with high accuracy and high throughput. Nucleic Acids Res. 32, 1792-1797.

Gordon, J.F. 1963. The nature and distribution within the plant of the bacteria associated with certain leafnodulated species of the families Myrsinaceae and Rubiaceae, p. 370. Thesis. Univ. London.

Huelsenbeck, J.P. and F. Ronquist. 2001. MRBAYES: Bayesian inference of phylogeny. Bioinformatics 17, 754-755.

Lemaire B., P. De Block, S. Van Oevelen, B. Verstraete, E. Smets, E. Prinsen, and S. Dessein. 2011. Identification of the bacterial endosymbionts in leaf nodulating Pavetta species (Rubiaceae). Int. J. Syst. Evol. Microbiol. Article in press.

Maddison, D.R. and W. P. Maddison. 2001. MacClade 4: Analysis of phylogeny and character evolution, version 4.01. Sinauer Associates, Sunderland, Massachusetts, USA.

Miller, I.M. 1990. Bacterial leaf nodule symbiosis. Adv. Bot. Res. 17, 163-243.

Murray, R.G.E. and E. Stackebrandt. 1995. Taxonomic note: implementation of the provisional status Candidatus for incompletely described prokaryotes. Int. J. Syst. Bacteriol. 45, 186-187.

Payne, G.W., P. Vandamme, S.H. Morgan, J.J. LiPuma, T. Coeyne, A.J. Weightman, T.H. Jones, and E. Mahenthiralingam. 2005. Development of a recA gene-based identification approach for the entire Burkholderia genus. Appl. Environ. Microbiol. 71, 3917-3927.

Posada, D. and K.A. Crandall. 1998. Modeltest: testing the model of DNA substitution. Bioinformatics $14,817-818$.

1. Rambaut, A. and A.J. Drummond. 2007. Tracer v1http://evolve.zoo. ox.ac.uk/software.html.

Robbrecht, E. 1978a. Sericanthe, a new African genus of Rubiaceae (Coffeeae). Bull. Nat. Plantentuin Belg. 48, 3-78.

Robbrecht, E. 1978b. Rubiaceae. Distr. Pl. Afr. 13: map 406-429.

Robbrecht, E. 1981. Studies in tropical African Rubiaceae (I). Bull. Nat. Plantentuin Belg. 51, 165-189.

Robbrecht, E. and J.F. Manen. 2006. The major evolutionary lineages of the coffee family (Rubiaceae, angiosperms). Combined analysis (nDNA and cpDNA) to infer the position of Coptosapelta and Luculia, and supertree construction based on $r b c L, \operatorname{rps} 16$, trnL-trnF and atpB-rbcL data. A new classification in two subfamilies, Cinchonoideae and Rubioideae. Syst. Geogr. Pl. 76, 85-146.

Ronquist, F. and J.P. Huelsenbeck. 2003. MrBayes 3: Bayesian phylo-genetic inference under mixed models. Bioinformatics 19, 1572-1574.

Simmons, M.P. and H. Ochoterena. 2000. Gaps as characters in sequence-based phylogenetic analyses. Syst. Biol. 49, 369-381.

Stamatakis, A. 2006. RAxML-VI-HPC: maximum likelihood-based phylogenetic analyses with thousands of taxa and mixed models. Bioinformatics 22, 2688-2690.

Tabacchioni, S., L. Ferri, G. Manno, M. Mentasti, P. Cocchi, S. Campana, N. Ravenni, and et al. 2008. Use of the gyrB gene to discriminate among species of the Burkholderia cepacia complex. FEMS Microbiol. Lett. 281, 175-182.

Tel-Zur, N., S. Abbo, D. Mylaboski, and Y. Mizrahi. 1999. Modified CTAB procedure for DNA isolation from epiphytic cacti of the genus Hylocereus and Selenicerus (Cactaceae). Plant Mol. Biol. Rep. 17, 249254.

Tosh, J., A.P. Davis, S. Dessein, P. De Block, S. Huysmans, M.F. Fay, E. Smets, and E. Robbrecht. 2009. Phylogeny of Tri c a ly s i a (Rubiaceae) and its relationships with allied genera based on plastid DNA data: resurrection of the genus Empogona. Ann. Mossouri. Bot. Gard. 96, 194-213.

Va $n$ Hove, C. 1972. Structure and initiation of nodules in the leaves of Neorosea andongensis (Hiern) N. Hallé. Ann. Bot. 36, 259-262.

Van Oevelen, S., R. De Wachter, P. Vandamme, E. Robbrecht, and E. Prinsen. 2002. Identification of the bacterial endosymbionts in leaf galls of Psychotria (Rubiaceae, angiosperms) and proposal of 'Candidatus Burkholderia kirkii' sp. nov. Int. J. Syst. Evol. Microbiol. 52, 2023-2027.

Van Oevelen, S., R. De Wachter, P. Vandamme, E. Robbrecht, and E. Prinsen. 2004. 'Candidatus Burkholderia calva' and 'Candidatus Burkholderia nigropunctata' as leaf gall endosymbionts of African Psychotria. Int. J. Syst. Evol. Microbiol. 54, 2237-2239.

Va $n$ Oevelen, S., E. Prinsen, R. De Wachter, and E. Robbrecht. 2001. The taxonomic value of bacterial symbiont identification in African Psychotria (Rubiaceae). Syst. Geogr. Pl. 71, 557-563.

Werle, E., C. Schneider, M. Renner, M. Volker, and W. Fiehn. 1994. Convenient single step, one tube purification of PCR products for direct sequencing. Nucleic Acids Res. 22, 4354-4355. 